
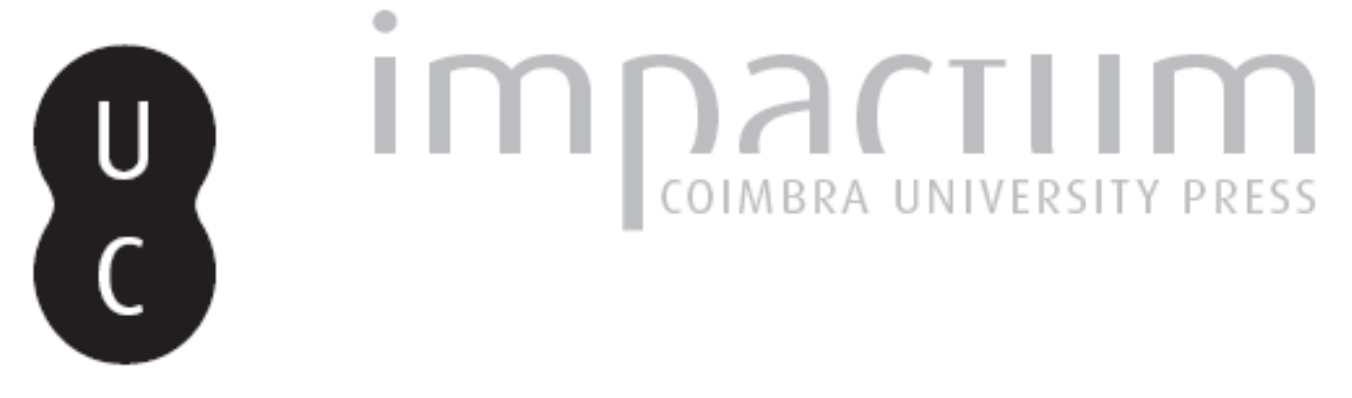

\title{
A construção do argumento no ensaio "Dioniso em Creta" de Eudoro de Sousa
}

Autor(es): $\quad$ Assunção, Teodoro Rennó

Publicado por: Annablume Clássica; Imprensa da Universidade de Coimbra

URL persistente:

URI:http://hdl.handle.net/10316.2/24345

DOI:

DOI:http://dx.doi.org/10.14195/1984-249X_8_9

Accessed : $\quad$ 26-Apr-2023 16:33:00

A navegação consulta e descarregamento dos títulos inseridos nas Bibliotecas Digitais UC Digitalis, UC Pombalina e UC Impactum, pressupõem a aceitação plena e sem reservas dos Termos e Condições de Uso destas Bibliotecas Digitais, disponíveis em https://digitalis.uc.pt/pt-pt/termos.

Conforme exposto nos referidos Termos e Condições de Uso, o descarregamento de títulos de acesso restrito requer uma licença válida de autorização devendo o utilizador aceder ao(s) documento(s) a partir de um endereço de IP da instituição detentora da supramencionada licença.

Ao utilizador é apenas permitido o descarregamento para uso pessoal, pelo que o emprego do(s) título(s) descarregado(s) para outro fim, designadamente comercial, carece de autorização do respetivo autor ou editor da obra.

Na medida em que todas as obras da UC Digitalis se encontram protegidas pelo Código do Direito de Autor e Direitos Conexos e demais legislação aplicável, toda a cópia, parcial ou total, deste documento, nos casos em que é legalmente admitida, deverá conter ou fazer-se acompanhar por este aviso.

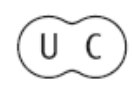


jan.2012

issn $2179-4960$

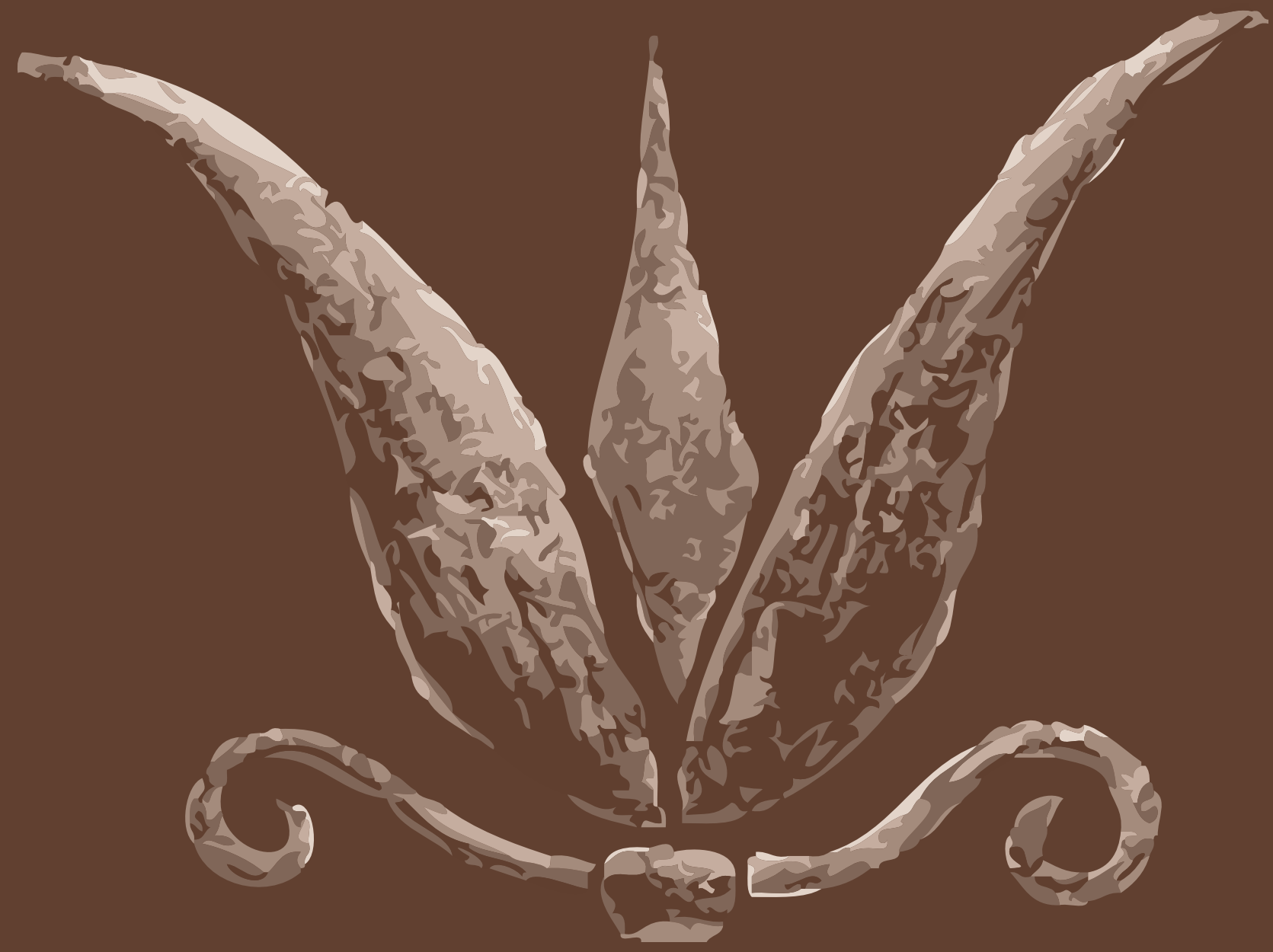

R E V I S T A
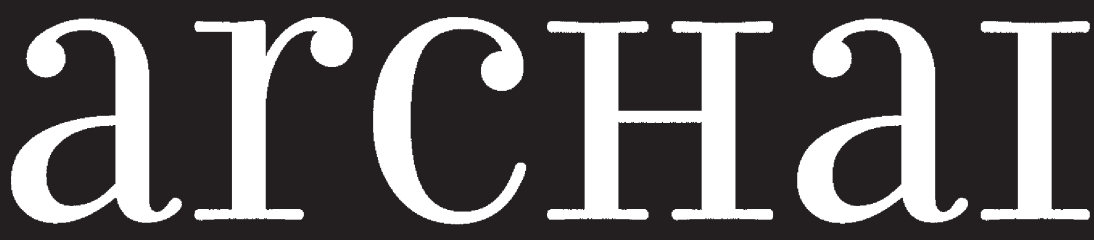

AS ORIGENS DO PENSAMENTO OCIDENTAL

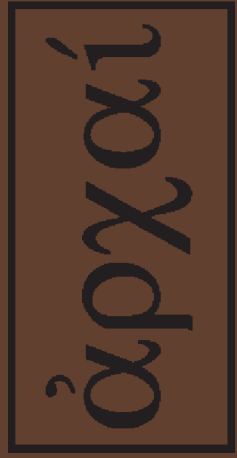

ARCHAI JOURNAL: ON THE ORIGINS OF WESTERN THOUGHT
arcHaI

AS ORIGENS DO PENSAMENTO OCIDENTA.

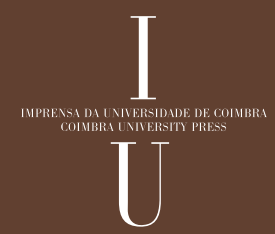

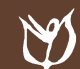




\section{A CONSTRUÇÃOO DO ARGUMENTO NO ENSAIO “DIONISO EM CRETA" DE EUDORO DE SOUSA}

ASSUNÇÃO, T. R. (2012). "A Construção do argumento no ensaio "Dionisio em creta" de Eudoro de Sousa". Archai n. 8, jan-jun 2012, pp. 87-94.

RESUMO: Este estudo breve visa apenas apresentar o modo de construção do núcleo do argumento do ensaio "Dioniso em Creta" de Eudoro de Souza, reservando-se - ao fazê-lo - distância suficiente para uma eventual crítica ou problematização.

PALAVRAS-CHAVE: construção, argumento, "Dioniso em Creta", Eudoro de Souza.

ABSTRACT: This brief study aims only at presenting the manner of construction of the nucleus of the argument of Eudoro de Souza's essay "Dioniso em Creta", reserving - in so doing - enough distance to criticize or call it into question.

KEY-WORDS: construction, argument, "Dioniso em Creta", Eudoro de Souza.
Teodoro Rennó Assunção*

A partir da proposição histórica básica de - Belo Horizonte - Brasil. Martin Persson Nilsson, não apenas da origem pré-helênica da mitologia grega, mas também, e sobretudo, da origem pré-helênica - isto é: creto-micênica - da religião grega, Eudoro de Souza se dispõe a fazer um ousado estudo de caso: 0 do deus grego Dioniso em suas conexões com a cultura minóica, ou seja, com a civilização cretense do segundo milênio a.C.

0 argumento - ou hipótese - dependerá, portanto, da interpretação dos achados arqueológicos em sua dimensão religiosa, isto é, dos achados da primeira metade do século XX em Cnosso, Festo, Malia, Haghia Triada, Gúrnia, Palaikastro e Thera, achados que não incluem documentos escritos, constituindo assim, na expressão de M. P. Nilsson citada por Eudoro, "um livro de imagens sem texto" (SOUSA, 1973, p. 12).

Eudoro de Souza começa lembrando os elementos mais característicos da vida religiosa cretense (ou minóica), além da estrutura dos palácios, tais como elencados em sua reconstituiç̧ão por Martin P. Nilsson:

1) a freqüentíssima figuração plástica de cenas culturais, em que intervém, com absoluto predomínio, uma divindade feminina; 2) a não menos freqüente estilização do bucrânio a que os ingleses chamam "horus 
of consecration'; 3) a lábrys ou bipene, machado de dois gumes, que, sem dúvida, foi instrumento de sacrificio do Touro Sagrado (...); e, finalmente, 4) os thóloi ou sepulturas circulares, cobertas por falsa abóbada, com acesso através de um 'drómos' mais ou menos extenso." (idem, p. 13).

Ora, como nota na sequência Eudoro, "só há notícia de uma cultura calcolítica [i.e. da transição do Neolítico para a Idade do Bronze] que parece reunir, na mesma área, esses quatro elementos característicos: thólos, bucrânio, lábrys e ídolos femininos, - é a de Halâf-Arpatchiah, na bacia do Eufrates." (idem, p. 13). Esta cultura matriz, segundo a hipótese de 1944, de Heinz Mode (em As primeiras culturas da Índia e suas relações com o Ocidente), citada por Eudoro, teria se difundido em dois ramos: “um para 0este, dando origem às primeiras civilizações do Mar Egeu, e outro para leste, promovendo o surto das civilizações pré-arianas do Vale do Indo, nomeadamente, Harappa e Mohenjo-Daro." (idem, p. 13). E é também na cultura de Halâf-Arpatchiah “que - segundo Eudoro - se presume haver nascido o culto da grande deusa egeo-anatólica, que tão relevante papel desempenhou na religião, ou nas religiões, da Grécia pré-helênica." (idem, p. 14).

Mas, antes de - ou para - retomar a significação religiosa dos quatro elementos característicos já citados, Eudoro irá apresentar e interpretar a estrutura arquitetônica comum dos palácios minóicos cretenses: “(...) na sua primeira fase, o palácio de Cnosso era constituído por blocos isolados e (...) a única relação entre aquelas 'insulae' era o espaço retangular que, ao fim e ao cabo, viria a formar 0 pátio central" (idem, p. 14).

(...) na sua forma definitiva, a concepção arquitetônica que se singulariza em toda a região egéica é, além da mencionada assimetria do conjunto, a função do pátio central, designadamente, o papel que desempenha como centro, fixo e inalterável, de um movente complexo periférico. (idem, p. 14-15).

Ora, esta função não seria a meramente arquitetônica ou prática de iluminação e arejamento, pois, segundo Eudoro, o pátio é um dado prévio, um princípio dinâmico, e não apenas o espaço que se mantém de reserva, no meio de contínua ou intermitente edificação de blocos; o pátio [cuja forma e grandeza seria a mesma em Cnosso, Mália e Festo] estaria para os edifícios circundantes em análoga relação em que o centro está para a circunferência descrita em torno dele. (idem, p. 15).

Eudoro de Souza resume e cita então em itálico - para aclarar esta função - a tese "inédita e surpreendente" do arqueólogo inglês J. W. Graham (American Journal of Archeology 1957, p. 255 e ss.): "no interior, precisamente no pátio central, e não em qualquer área exterior, próxima ou distante dos palácios, é que se realizavam as tauromaquias celebrizadas por tão elevado número de testemunhos figurados." (SOUSA, 1973, p. 15-16), aduzindo também a suspeita - a partir de um comentário de Charles Picard (Révue Archéologique 1958, p. 89-90) - de que as "corridas" de touro cretenses ultrapassassem em muito, por sua importância social nuclear, a mera dimensão profana de "simples prazer de áulicos ou divertimento do povo." (SOUSA, 1973, p. 16).

Ora, a solução religiosa de Eudoro para a tauromaquia minóica - inovação ousada que não se encontra nem em J. W. Graham nem em Charles Picard - será simultaneamente uma solução para um elemento patente (e que poderia constituir problema) da religião minóica: o predomínio ou exclusividade da grande divindade feminina (que Eudoro chama então de Magna Mater) e a ausência nestes documentos arqueológicos de uma divindade masculina, ausência que - segundo uma antecipação de Eudoro - resultaria, "mais provavelmente, de que sua presença permanece oculta sob figuras simbólicas." (idem, p. 16).

Eudoro retoma então dois dos citados quatro elementos característicos desta religião:

Entre tais figuras, a lábrys e o bucrânio trazem em si a irresistível força da evidência. Não é fácil furtar-nos à suspeita de que a primeira fosse instrumento de sacrificio, e recusar-nos a vermos na segunda a vítima sacrificada. As pinturas do famoso sarcófago de Haghia Triada e alguns exemplares da glíptica minóica são inequívocos testemunhos do sacrifício do touro. (idem, p. 16). 
É aí então que Eudoro - sem explicitar as razões ou provas documentais do seu procedimento - transferirá ou estenderá a sacralidade do ato sacrificial (ou do seu destinatário) para a vítima do sacrifício (o touro), que - por analogia com o exemplo de Cristo e o rito da comunhão na missa ele identificará à divindade:

Consinta-se na impressão de intransponibilidade dos obstáculos que se nos deparam, querendo abolir a diferença que aparta a vítima que se sacrifica a uma divindade, da própria divindade em cuja devoção ela é sacrificada. Do touro-oblato ao deus-touro, insuperável se nos afigura a distância, embora a religião cristã sobre bem mais fundo abismo tenha lançado a ponte que diariamente atravessamos, mal apercebidos do Mistério. (idem, p. 16-17).

0 salto, no entanto, será ainda maior e mais arriscado quando Eudoro - também sem comprová-lo e sem que saibamos como - fizer da tauromaquia nos pátios centrais dos palácios um grande rito de sacrifício do touro-deus (e mesmo do rei) com uma presumível função básica de renovação periódica da vida social e natural:

Queremos (...) deixar claramente expressa a ideia de que o grande pátio dos palácios de Creta, encimados por enormes bucrânios e ornamentados com inúmeras e várias estilizações da lábrys, teria de constituir o centro de todo o complexo arquitetônico, precisamente porque nele se representava o grande ato de um drama mediante o qual, de tempos a tempos, se reinstituía na hierarquia social o princípio ou a potência divina que lhe dera origem. Efetivamente, há motivos para crer que, pelo menos em Cnosso, 'Minos' era título do rei e nome do touro. (idem, p. 17).

Infelizmente, nenhuma nota de Eudoro explicita quais são estes motivos e - dando por assentes suas hipóteses - ele passa de imediato à seguinte questão: "será possível atribuir algum nome grego, ou que - uma vez grecizado - se tenha tornado corrente entre os gregos, ao deus-touro, tão celebrado no Mutus Liber da cultura minóica?" (idem, p. 17).
Para chegar a Dioniso como resposta, Eudoro propõe primeiro que se aceite, "como não fantasiosa, a localização cretense do ritual de Zagreus, que se nos depara em um discutido fragmento de Eurípides e numa não menos discutida página de Firmicus Maternus" (idem, p. 17) - ainda que, informados apenas assim, não fique claro porque, segundo Eudoro, "teríamos, por evidente, que o touro também é uma epifania de Dioniso" -, levando em conta também que a combinação do mito de Zeus Kretagénes com o de Europa resultaria "em que o touro é uma epifania crética do Soberano do Olimpo" (idem, p. 17), o que porém não seria problema, uma vez que os órficos “sabiam que 'Zeus-Cretense' e 'Dioniso Zagreus' podiam designar dois aspectos de uma mesma divindade que nasce, morre e ressuscita, e que ambos os aspectos coincidiam na mesma epifania tauromórfica." (idem, p. 18).

Em segundo lugar, Eudoro - mesmo admitindo, ao longo de sua bi-milenar história, alguma absorção pelo dionisismo grego de traços "mais pertinentes a divindades asiáticas essencialmente afins" (idem, p. 18) - propõe com razão uma revisão crítica da opinião comum (communis opinio) de que "o culto de Dioniso na Grécia só admitiria uma origem histórica na Trácia ou na Frígia" (idem, p. 18) [pois como sabemos hoje, e já Eudoro sabia em seu tempo, a decifração do linear B por Michel Ventris mostrou que o deus já era conhecido na civilização micênica], devendo-se também repensar, como sugere Eudoro, uma adesão imediata aos "testemunhos da tradição literária, que, a partir de Homero, vêm afirmando e reafirmando que na Grécia o deus é um intruso e, em princípio, um indesejável" [ainda que sua caracterização como estrangeiro possa fazer parte do seu modo mesmo de ser, podendo ele ser definido, segundo uma sugestão de Marcel Detienne, como "um estrangeiro do interior" (DETIENNE, 1986, p. 21-27)], fazendo parte de sua tradição (em várias estórias além das de Licurgo, contada no canto VI da Ilíada, e de Penteu, contada n'As Bacantes) uma "resistência à difusão do culto báquico", que, como sugere Eudoro citando Guthrie, poderia “não ser mais que um protesto da razão derrotada 'pelos elementos de bestiality que ordinariamente dormem em cada ser humano'." (SOUSA, 1973, p. 18). 
Mas se para Eudoro "nada obstaria a que déssemos o nome de Dioniso ao Touro Divino da ilha de Creta", a questão decisiva é outra: "a de saber se, em Creta, ao acólito ou paredro da grande divindade feminina, cuja epifania é o touro [hipótese que, como vimos, ainda necessitaria ser demonstrada], nós devemos atribuir o nome de Dioniso, com fundamento na percepção de uma essencial identidade entre o deus cretense e o deus grego." (idem, p. 19).

A chave para a positiva identificação do hipotético deus-touro cretense com o Dioniso grego está em uma (não estritamente filológica) ideia de Kerényi (exposta do artigo "Dionysos Le Crétois", Diogène 20, 1957, p. 2-27 e no livro Der frühe Dionysos, 0slo, 1961), que seria confirmada pelas interpretações iconográficas de conjunto da arte minóica por Friedrich Matz (sobretudo Göttererscheinung und Kultbild im minoischen Kreta, 1958) e H. A. Groenwegen-Frankfort (em Arrest and Movement. An Essay on Space and Time in the representational Art of the ancient Near East, London, 1951), ideia que Eudoro entusiasticamente qualifica como "a mais original de quantas registra a 'Altertumswissenschaft', resumindo-a assim (com o destaque do itálico):

a arte minóica, a arte de Creta em conjunto, e não apenas em tal ou tal objeto, em uma ou outra das suas formas singulares, encontra-se toda ela impregnada de 'dionisíaco', daquele mesmo espírito de ebriedade e loucura que transparece com tão sombrio fulgor nos versos das Bacantes. (SOUSA, 1973, p. 19-20).

Vemos, assim, nesta definição comparativa, o quão essencial é para o dionisismo (e suas possíveis origens cretenses) a interpretação dos "dados" apresentados em uma obra literária consagrada como As Bacantes. Ora, o esboço de interpretação deste "espírito de ebriedade e loucura" que Eudoro apresenta na sequência é demasiado sucinto (demandando, portanto, ulteriores explicitações), quando não resvala na simples paráfrase condensada. Primeiramente, segundo Eudoro, "a tempestade emocional (...) em que o indivíduo se distrai da própria individualidade e da razão pragmática que o insere na ordem social instituída", assim como "o êxtase, loucura e embriaguez da vida de ‘uma natureza que não conhece o homem, e em que o homem não se reconhece'(...)"; e, em segundo lugar, esta parte de sua definição de Dioniso:

deus mainómenos, enlouquecido e enlouquecedor, que se compraz no tumultuoso tropel das Mênades e das Bacantes, - deus das mulheres que, percorrendo desvairadas uma terra toda ela convertida em seio ubérrimo, donde brotam o leite e o mel, cingidas de serpentes e coroadas de hera, amamentam as bestas feras, para logo as destroçarem, por suas mãos já esquecidas do gesto vivificante; (...). (idem, p. 20). ${ }^{1}$

Mas é apenas na imensa e decisiva nota 31 que encontraremos uma descrição - a partir dos já citados trabalhos de F. Matz e H. A. Groenwegen-Frankfort - das " 'leis' da sintaxe ornamental da arte minóica" que "sugeriram a presença de Dioniso em Creta". Primeiramente, a definição do estilo voluminal (do latim volvere) pelas "três características interconexas do 'movimento rodopiante', da 'torsão' e do 'rapport infinito', que nos aspectos mais evidentes da pintura cerâmica e da figuração sigilográfica tendem respectivamente a se representar no esquema simples da 'dupla espiral', (...) na disposição dos motivos obliquamente em relação ao eixo do vaso (...) e a repetição simples de um só motivo, ou alternada, de dois ou mais motivos, em torno de toda a superfície do vaso (...)." (idem, p. $51)$. $E$, em segundo lugar, o que sugere uma longa citação por Eudoro do penúltimo capítulo do livro de Groenwegen-Frankfort dedicado aos afrescos palaciais (e da qual faremos o seguinte recorte):

Ludwig Curtius, numa bela e poética paráfrase às cenas, caracterizou-as como 'überhaupt Leben', - vida absoluta. A frase bem podia servir de mote para qualquer exposição sobre a arte cretense, pois o movimento - movimento orgânico - parece ser a verdadeira essência dela: movimento no animal ou no homem, nas flores agitadas pelo vento, com pétalas que se desprendem e caem, nos troncos de trepadeiras que se retorcem subindo fragas, as próprias rochas que parecem substância mal solidificada. (...) Se tivermos de caracterizar o tipo de movimento fragmentariamente representado, o termo 'mobilidade absoluta' é o que naturalmente nos é sugerido: reco-
1. Para uma tentativa de interpretação do êxtase dionisíaco (para a qual aquaela do que é sugerido pela peça As Bacantes continua a ser essencial) ver o artigo recente de Renate Schlesie “''extase dionysiaque et l'histoire des religions" (SCHLESIER, 2007). Obviamente esta indicação extrapola o objetivo primeiro deste nosso breve ensaio e não poderíamos jamais exigir absurdamente de Eudoro de Sousa uma atualização bibliográfica que ultrapassasse o tempo em que o seu artigo foi escrito; mas imaginar, por outro lado, o quanto deve ter se modificado desde então o saber arqueológico (assim como o da história das religiões) e o que isso traria para uma avaliação de conjunto das suas proposições poderia nos lançar na oportuna vertigem da percepção do quanto são fatalmente datadas e circunscritas historicamente mesmo aquelas tentativas mais ousadas e que pretendem transcender o seu tempo, acenando para um futuro indeterminado. Se nos voltássemos, enfim, rapidamente, para o tema maior em questão, o deus grego Dioniso, seria certamente inumerável a bibliografia aparecida desde 0 ano de publicação do ensaio de Eudoro de Sousa (que então era certamente - o que não é nem um pouco desprezível extremamente bem informado bibliograficamente), o que nos leva, portanto, a apenas querer lembrar de dois livros publicados mais recentemente: Dionysos de Richard Seaford (SEAFORD, 2006) e Dionysos und das Dionysische in der antiken und deutschen Literatur de M. L. Baeumer (BAEUMER, 2006). 
nhecido paradoxo lógico que só poderia justificar-se, tratando-se de uma ameba e de moluscos movendo-se no meio sem resistência dos mundos aquáticos, ou (...) no caso de pássaros voando. (...) Nas cenas de Creta, o movimento parece não exigir esforço; é a qualidade que se resume no 'galope volante' (a mais cretense das invenções) e que se reconhece também nos dançarinos 'flutuantes', cujos pés pendem vacilando, em vão, de tal maneira que as figuras balançam parecendo desligadas da terra (...). (...) 0 mais notável ainda, é o fato de os Cretenses muitas vezes pintarem os seus deuses explicitamente como criaturas nascidas no ar, cuja epifania ocorre como a descida de um pássaro, com os cabelos tendendo para o alto e os pés apontando para o solo. (idem, p. 52-53).

Após a citação, Eudoro comenta que esta passagem introduz, no final, uma súmula da tese de F. Matz de

que em épocas ainda isentas de influxos culturais do continente europeu ou asiático, não existem figuras plásticas das divindades cultuadas, e que as representações existentes são as de lugares consagrados pelas epifanias de deuses, cuja aparição se dá ao fim e ao cabo de uma preparação do êxtase propiciatório (pela dança?, pelo uso do ópio e do vinho?, por ambos os meios simultaneamente?). (idem, p. 53).

Ora, o que não é explicitado por Eudoro - que parece proceder por uma tácita analogia formal sugerida apenas pela mera justaposição de "dados" - é a conexão precisa entre o "espírito de ebriedade e loucura que transparece nas Bacantes" (também definido algo rapidamente por Eudoro) e - primeiro - "o movimento rodopiante" e "a torsão" que caracterizam o estilo voluminal (perguntamo-nos: seria algo dos gestos, mais especificamente da dança executada pelas Mênades em transe? mas onde então nas Bacantes encontraríamos uma indicação de ou alusão a um tal tipo de movimento precisamente?) e - em segundo lugar - a "mobilidade absoluta" (ou "movimento orgânico") reconhecível como padrão formal para as cenas dos afrescos palaciais minóicos (também nos perguntamos: seria a mobilidade constante e um certo desenraizamento de "estran- geiro" - como sugere M. Detienne em Dionysos à ciel ouvert (DETIENNE, 1986) - uma característica tanto de Dioniso quanto das Bacantes na peça que tem este último nome?).

Restaria, enfim, demonstrar - o que também não é nada óbvio - como podem ser aproximados ou identificados dois planos ou duas ordens de fenômeno bem distintos: o "espírito de ebriedade e loucura" marcadamente ritualístico das Bacantes na peça homônima e a sintaxe ornamental da arte minóica com padrões formais como o "movimento rodopiante" e "a torsão", ou ainda "a mobilidade absoluta" em cenas que não necessariamente representam rituais religiosos afins a este deus. Também a afirmação de Kerényi, aduzida na sequência, continua a demandar uma semelhante explicitação das conexões entre 0 conjunto da arte minóica e o deus Dioniso:

(...) a impressão de dionisíaco que a arte minóica nos comunica pode ser composta em elementos concretos que na Grécia só o culto de Dioniso reúne de forma similar: (...) como deus do vinho, deus touro e deus das mulheres, - deus, igualmente, das divindades de caráter extático, das quais a maior foi Réia, Mãe dos Deuses. (idem, p. 21).

É também de se suspeitar a demasiado genérica associação entre o "naturalismo minóico" como "a arte de pintores e escultores fascinados pelo elemento líquido e o reino vegetal" - tal como definida por W. Schadewaldt em 0 mundo das imagens homéricas e a arte creto-micênica (1943) - e a seguinte definição do deus pelo próprio Eudoro:

Deus do elemento líquido, que, perseguido por Licurgo, se lança no mar, depósito imenso e inesgotável do princípio que, como seiva ou sangue ou sêmen, sustenta toda a vida vegetal e animal; 'deus da árvore', dendrites ou éndrendos, e deus phloios consubstanciado nas plantas verdes e nas flores das árvores frutíferas (...)". (SOUSA, 1973, p. 20).

Além da assimilação do mar (com que o deus está conectado em alguns episódios ou ritos) com o "princípio que, como seiva ou sangue ou sêmen, sustenta toda a vida vegetal e animal", ou seja: um 
úmido vital - tal como reconhecido por Walter F. Otto (0TT0, 1969, p.169-179) - mas que dificilmente se confundiria com o líquido salgado e estéril (cf. o epíteto homérico atrýgetos) do mar, também é de se estranhar que "o elemento líquido" (sobretudo o marítimo) e "o reino vegetal" que fascinaram os artistas minóicos - mas que podem também por sua amplidão estar presentes em várias outras artes que não a creto-micênica - sejam identificados precisamente como dionisíacos, quando, por exemplo, o mar também poderia (dependendo da cena) ser associado ao deus Posseidon (a que, coincidentemente, também o touro era associado), assim como o reino vegetal (segundo o tipo da cena) a divindades como Deméter ou Ártemis. Será, pois, necessariamente dionisíaca, como o quer Eudoro, "aquela indiscutível presença da água no afresco dos delfins ou num vaso pintado no exclusivo propósito de fixar os movimentos de um polvo em seu elemento natural" (SOUSA, 1973, p. 22)? Ou, ainda, necessariamente dionisíaca “a, digamos assim, 'existência vegetativa' das flores (...) em afrescos como 'a colheita do açafrão' e 'o pássaro azul"' (idem, p. 22) ou mesmo a figura conhecida do "Príncipe da Coroa de Penas" pelo fato de que "pareça ondular ao vento, como o caule dos lírios em seu redor" (idem, p. 22)?

Há, enfim, um último e importante elemento a ser considerado por Eudoro neste complexo religioso minóico-grego: o êxtase como fenômeno cultural - elemento que, por sua vez, lançará a questão conclusiva do núcleo do ensaio que é a da relação de Dioniso (enquanto paredro) com a grande divindade feminina (a Magna Mater) recorrentemente atestada em Creta. Eudoro, começando, diz assim: “Fora do quadro, portanto, só resta o caráter extático, comum à religião cretense e pré-helênica e à religião grega e dionisíaca. Que o êxtase, natural ou provocado, é, digamos, a própria substância de ambos os cultos, parece fato indiscutível." (idem, p. 22). E então corta abrupto: “Mas, daí por diante, cessa toda a analogia." (idem, p. 22). Mas, apesar da reserva presente no uso da negação, Eudoro - como as longas e cuidadas notas 44 e 45 parecem também confirmar - parece, na sequência, estar considerando seriamente a possibilidade de um êxtase provocado pelo ópio nos cultos minóicos:
Já não falamos, sendo o êxtase provocado, em que as 'portas da percepção' (44) se abrem sob a ação entorpecente do vinho, na Grécia, e do ópio, em Creta (45). Com efeito, as cápsulas de Papaver Somniferum, daquela espécie de papoula que adorna a cabeça do idolo de Gazi, ostentam o golpe efetuado para a extração do alcalóide, e na expressão fisionômica do ídolo reconhecem-se os traços característicos do opiômano. Porém, repare-se, o ídolo de Gazi é feminino, como os demais ídolos de Creta; por conseguinte representaria ou uma deusa farmacopéica ou uma hipóstase farmacopéica da única deusa de Creta. (idem, p. 22-23).

A expressão com aspas "portas da percepção" mobiliza a nota 44, espaço da única discussão neste ensaio do efeito anímico da embriaguez (e, analogicamente, do êxtase) provocado por drogas. ${ }^{2}$ A expressão - que é de William Blake - é uma referência ao título do conhecido livro de Aldous Huxley sobre seus experimentos com a mescalina (que obviamente pode se distinguir muito, enquanto alucinógeno, de drogas como o vinho e o ópio). Mas o que Eudoro capta no ensaio de Huxley como operação anímica básica desta droga pode - mesmo se distinta da do vinho mas talvez nem tanto da do ópio - eventualmente se aproximar em algo da ruptura com o estabelecido implícita na entrega a uma divindade transgressora e desindividualizante como Dioniso.

"Em Huxley," segundo Eudoro, “o entorpecente age (...) como eliminador da razão pragmática." (idem, p. 53). E ele cita então esta demonstrativa passagem do próprio Huxley: “Embora o intelecto nada sofra e a percepção seja grandemente aumentada (sob a ação do entorpecente) a vontade experimenta uma grande transformação para pior. 0 indivíduo que ingere mescalina não vê razão para fazer seja o que for, e considera profundamente injustificável a maioria das causas que, em circunstâncias normais, seriam suficientes para motivá-lo a agir. Elas não o preocuparão, pela simples razão de ter ele melhores coisas em que pensar." (idem, p. 54). E, associando-a também ao êxtase ritual dionisíaco, Eudoro lembra da descrição de Ludwig Klages (de preferência à de Bergson) do êxtase provocado por entorpecentes:
2. Talvez coubesse aqui uma breve nota sobre a importância estrutural das notas (no caso, de fim de texto) no ensaísmo de Eudoro de Souza, onde elas desempenham não só a função bibliográfica básica de informação quanto às referências, mas também aquela de suporte à argumentação com a apresentação circunstanciada das hipóteses por meio de citações maiores dos autores convocados assim como da apreciação crítica destes. Diríamos, pois, sem medo da banalidade, que a erudição de Eudoro jamais é meramente ornamental ou recurso vazio e de aparato para a autorização acadêmica - cf. as irônicas considerações sobre a assim chamada "the Wilamowitz Footnote" no lúcido artigo de Steve Nimis "Fussnoten: das Fundament der Wissenschaft" (NIMIS, 1984, p. 114-130). Por vezes, temos mesmo a estranha impressão - que inverte um pouco a perspectiva meramente utilitária no uso deste recurso - de que algo de essencial ao argumento foi deslocado para as notas, que assim não poderiam de modo nenhum deixar de ser lidas. 0 desconcertante efeito retroativo de uma tal percepção seria figurar o próprio texto do artigo como uma imensa nota autônoma e prioritária em relação a um texto inexistente. 
Em todo o caso, afigura-se-nos que na obra de Klages a descrição do êxtase, como libertação do composto, ou melhor, da complementaridade corpo-alma, das garras vampirescas do espírito (inteligência e vontade pragmáticas que deixam, em cada vivente humano, os sulcos indeléveis a que chamamos 'personalidade'), se avantaja enormemente à outra, que constitui o êxtase em libertação do espírito, do cárcere corpóreo. (idem, p. 54).

Podemos duvidar, no entanto, de que os efeitos do vinho e do ópio sejam análogos e de que ambos poderiam provocar um mesmo tipo de êxtase (chamado então de dionisíaco), pois se nos lembramos do que sugere comparativamente Baudelaire nos Paradis artificiels (BAUDELAIRE, 1973, p. 377-398), enquanto o vinho é socializante, excita a dramaticidade e opera uma abertura para o outro própria à festa, o haxixe (e, por extensão, o ópio), apesar (ou pelo fato) de potenciar a acuidade sensorial e metafísica, enfraquece a vontade e indispõe paranoicamente o indivíduo para o contato social. Assim, pois, tanto pelos testemunhos do linear B [em que Dioniso (diwonisojo) já aparece associado ao vinho (wonowatisi "senhor do vinho"), segundo a revelação de J. W. Graham em The Palaces of Crete de 1962, citada por Eudoro na nota 45] quanto pelos testemunhos literários e 'etnológicos' da idade arcaica e clássica (cf., por exemplo, o fragmento 120 W de Arquíloco e As Bacantes), não há porque duvidar da associação tradicional do deus ao vinho, mas estendê-la ao ópio - que não entra no repertório do deus grego - nos parece um passo arriscado e indemonstrável, sobretudo se o testemunho iconográfico minóico - o opiômano ídolo de Gazi - se apresenta isolado (e não em grupo) em uma cena que não necessariamente tem conotações ritualísticas precisas e que, ademais, não se integra em uma série maior de cenas do mesmo tipo.

Restaria, enfim, apresentar rapidamente a solução de Eudoro para o problema - suscitado pelo caráter feminino do opiômano ídolo de Gazi - da predominância da deusa-mãe na Creta minóica e da sua relação com o deus-paredro (no caso, Dioniso-Touro, segundo a hipótese de Eudoro). Pois, como Eudoro o formula, "todos os monumentos nos inclinam a considerar a Grande-Deusa da Ilha de Minos como figura muito mais poderosa e importante que o Touro ou o Arbusto divinos, mesmo que the possamos ou devamos dar o nome de Dioniso." (SOUSA, 1973, p. 23). Mas - considerada esta koiné cultural do II milênio a. C., que abrange todo o Egeu e o Oriente Próximo, e vai do Indo ao Adriático e do Helesponto ao Vale do Nilo, koiné onde uma grande deusa é sempre acompanhada de um deus menor - o que mais impressiona Eudoro é

verificar que, por um lado, no ritual da paixão, morte e ressurreição do deus, cuja epifania é uma planta, a Grande-Deusa não parece haver exercido papel condigno do tal poder e importância que lhe atribuem; e que, por outro lado, às vezes é ela mesma quem protagoniza o próprio drama da paixão - é o caso, por exemplo, de Deméter-Perséfone, na Grécia, e de Innana-Ishtar, na Macedônia. (idem, p. 26).

Ora, esta aparentemente insolúvel contradição poderia ser resolvida pelo seguinte e desenvolto passo de Eudoro:

proponhamos (...) que a maior importância e o maior poder ou - em conceituação menos vaga e menos abstrata - a imortalidade de Deméter, Cibele, Anat, Astartê, Ísis e Ishtar, diante da mortalidade de seus assessores e acólitos, traduz simplesmente um fenômeno de 'contaminação'. (...) Perséfone, Átis, Baal, Adônis, Osíris, Tammuz e, talvez, Dioniso, mantendo a maior parte de suas originais características de divindades-dema, encontram-se, por fim, subordinados a uma deusa-mãe, na qualidade de filhos ou amantes; de qualquer modo, como acólitos ou 'paredros'. (idem, p. 28).

Nesta assimilação final que não consegue de modo algum, nos termos mesmos da formulação, apagar as nítidas diferenças entre dois tipos distintos de divindade, Eudoro tentará arrematar assim:

(...) julgamos que não seja por demais audacioso asseverar que radical, ou seminal, não seria a diferença que separa a Grande Deusa minóica do deus fitomórfico ou tauromórfico, ao qual conviria a o nome de Dioniso. Por isso, sempre se poderia repartir entre as duas divindades, originariamente afins, o caráter extático 
que, em épocas mais recentes, continua aderindo ao culto da Réia-Cibele anatólica e do Dioniso helênico. (idem, p. 29).

Enfim, para concluirmos esta breve apresentação da construção do núcleo do argumento de "Dioniso em Creta" (pensada, a princípio, para uma comunicação de - no máximo - meia hora, em um evento comemorativo acontecido em junho de 2008), gostaríamos apenas de lembrar que com ela rendemos uma justificada e modesta homenagem à erudição imaginativa de Eudoro de Souza, através dos básicos recortes e da montagem de várias citações que dão prazerosamente voz a este autor cujo vasto repertório de informações (sobretudo as arqueológicas) confessamos não estar em condições de avaliar criticamente, mas que também tentamos - ao problematizar certas proposições e o modo mesmo de construção das hipóteses - nos distanciar minimamente do autor para tentar pensar com algum recuo os seus procedimentos, o que certamente é um modo de homenagem menos evidente e que, em sua radical liberdade (mais atenta ao discurso e a seu objeto do que à sua autoria), sempre corre 0 incômodo risco do mal-entendido. Se, então, como uma última palavra, nos fosse permitido ousar um rápido balanço crítico desta tentativa de Eudoro de Souza, talvez o que primeiro questionaríamos fosse a excessiva importância atribuída à origem como via privilegiada de acesso a um fenômeno (pressuposto metódico que não deixa de remeter, por exemplo, ao Nietzsche d'A origem da tragédia ou às especulações etimológicas do segundo Heidegger), quando o fenômeno enquanto tal, no caso o deus Dioniso, dado como compreendido em suas "documentações" mais conhecidas - como As Bacantes de Eurípides ${ }^{3}$ - restaria aí mesmo ainda a ser pensado e discutido com mais calma e precisão.

\section{REFERÊNCIAS BIBLIOGRÁFICAS}

BAEUMER, M. L. (2006). Dionysos und das Dionysische in der antiken und deutschen Literatur. Darmstadt: Wissenschaftliche Buchgesellschaft.

BAUDELAIRE, C. (1973). Du vin et du hachisch, comparés comme moyens de multiplication de l'individualité. In: Les paradis artificiels. In: CEuvres complètes I. Paris, Gallimard, p. 377-398.

BOLLACK, J. (2005). Dionysos et la tragédie: Le Dieu homme dans les "Bacchantes" d'Euripide. Paris, Bayard.

DE SOUZA, E. (1973). Dioniso em Creta. In: Dioniso em Creta e outros ensaios. São Paulo, Duas Cidades, p. 7-71.

DETIENNE, M. (2000). Dionysos à ciel ouvert. Paris: Hachette, 1986. FRANKLIN, D. Euripides, Bacchae. A New Translation and Commentary. Cambridge, Cambridge University Press.

NIMIS, S. (1984). Fussnoten: das Fundament der Wissenschaft, Arethusa, Baltimore, vol. 17-2, p. 105-134.

OTTO, W. F. (1969). Dionysos: le mythe et le culte (trad. Patrick Lévy). Paris, Mercure de France.

SCHLESIER, R. (2007). L'extase dionysiaque et l'histoire des religions, Savoirs et clinique, Paris, no 8, p. 181-188.

SEAFORD, R. (2006). Dionysos. London/New York, Routledge.

SEGAL, C. (1982). Dionysiac Poetics and Euripides' Bacchae. Princeton, Princeton University Press.

Recebido em novembro de 2011. Aprovado em dezembro de 2011.
De uma grande bibliografia sobre esta peça (e, particularmente, sobre o papel de Dioniso nela) gostaríamos apenas de lembrar três títulos significativos publicados após o ensaio de Eudoro de Souza: Dionysiac Poetics and Euripides' Bacchae de Charles Segal (SEGAL, 1982), Euripides, Bacchae. A New Translation and Commentary de D. Franklin (FRANKLIN, 2000) e Dionysos et la tragédie: Le Dieu homme dans les "Bacchantes" d'Euripide de Jean Bollack (BOLLACK, 2005). Para a modesta função informativa desta presente nota (que eventualmente a tornaria um justo alvo da já citada crítica de Steve Nimis), ver o que já foi dito na nota 1. 